\title{
Re Original Contribution \\ INHIBITION OF HYPOCHLOROUS ACID-MEDIATED REACTIONS BY DESFERRIOXAMINE. IMPLICATIONS FOR THE MECHANISM OF CELLULAR INJURY BY NEUTROPHILS
}

\author{
Margret C. M. Vissers* and J. C. Fantone \\ Department of Pathology, University of Michigan Medical School, Ann Arbor, MI 48109
}

(Received 21 March 1989; Accepted 13 December 1989)

\begin{abstract}
Inhibition of free radical mechanisms by desferrioxamine, an iron chelator, is often thought to be a good indicator of iron-catalyzed hydroxyl radical $\left(\mathrm{OH}^{-}\right)$production. The specificity of desferrioxamine is critical for such identification. This study was undertaken to determine whether desferrioxamine could prevent the in vitro cytotoxic reactions of hypochlorous acid $(\mathrm{HOCl})$, a major neutrophil-derived oxidant. Red blood cells were used as a target for $\mathrm{HOCl}$, and cell lysis and haemoglobin oxidation were measured. Desferrioxamine, and its ironchelated form, ferrioxamine, were shown to prevent both effects of HOCl. However, desferrioxamine was 6 to 8 times more efficient than either ferrioxamine or taurine, another amine which prevents HOCl-mediated cell lysis, in preventing both lysis and $\mathrm{Hb}$ oxidation. After reaction with $\mathrm{HOCl}$, ferrioxamine and taurine retained almost all the oxidizing equivalents as long-lived chloramine. However, with desferrioxamine less than half the oxidizing equivalents were recovered as chloramines indicating that sites other than the terminal amine reacted with $\mathrm{HOCl}$. The chloramines formed were able to oxidize molecules in solution, but being hydrophilic they were confined to the extracellular medium and cell lysis did not occur. The results indicate that scavenging of $\mathrm{HOCl}$ could be a factor in the inhibition by desferrioxamine of neutrophil-mediated cell lysis in vitro.
\end{abstract}

Keywords-Desferrioxamine, Hypochlorous acid, Neutrophils, Free Radicals

\section{INTRODUCTION}

Phagocytic cells, particularly polymorphonuclear leukocytes (neutrophils), produce high concentrations of activated forms of oxygen when stimulated. ${ }^{1.2}$ These oxidants play a major role in the pathogenesis of acute inflammation, contribute to tissue injury in the lung, joint, and kidney, and may be involved in ischemia reperfusion injury. ${ }^{3-6}$

Although evidence for the role of neutrophil-derived oxidants in mediating tissue injury is convincing, ${ }^{3-6}$ identification of the oxidant species responsible has proven elusive. Determination of the responsible oxidant is dependent on the use of inhibitors. However, the lack of specificity of many inhibitors or scavengers complicates the identification of the oxidants, particularly the hydroxyl radical $\left(\mathrm{OH}^{*}\right)$, which is extremely reactive. Desferrioxamine, an iron chelator which re-

Present address and address for correspondence: Department of $\mathrm{Pa}$ thology, Christchurch School of Medicine, Christchurch Hospital, Christchurch, New Zealand. moves the iron catalyst required for $\mathrm{OH}^{*}$ production, has been widely used to implicate the involvement of $\mathrm{OH}^{*}$ in neutrophil-mediated events. Inhibition by desferrioxamine, coupled with an inability of the ironsaturated form, ferrioxamine, to prevent oxidant-mediated injury, has been taken as evidence of iron-mediated $\mathrm{OH}^{\cdot}$ reactions. ${ }^{7-10}$

Desferrioxamine and ferrioxamine, however, are amines (Fig. 1), and would be expected to react with hypochlorous acid ( $\mathrm{HOCl})$, which is produced by neutrophils and monocytes. Myeloperoxidase, an azurophil granule enzyme, catalyzes the reaction:

$$
\mathrm{H}_{2} \mathrm{O}_{2}+\mathrm{Cl}^{-}+\mathrm{H}^{+} \longrightarrow \mathrm{HOCl}+\mathrm{H}_{2} \mathrm{O}
$$

$\mathrm{HOCl}$ is a potent oxidant which reacts readily with a wide range of biological molecules. ${ }^{11-14}$ On reaction with amines, chloramine derivatives containing the $\mathrm{N}-\mathrm{Cl}$ bond are formed ${ }^{15-17}$

$$
\mathrm{HOCl}+\mathrm{RNH}_{2} \longrightarrow \mathrm{RNHCl}+\mathrm{H}_{2} \mathrm{O}
$$


A.

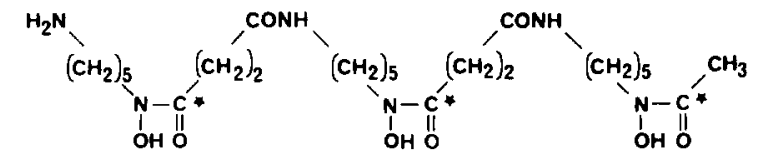

B.

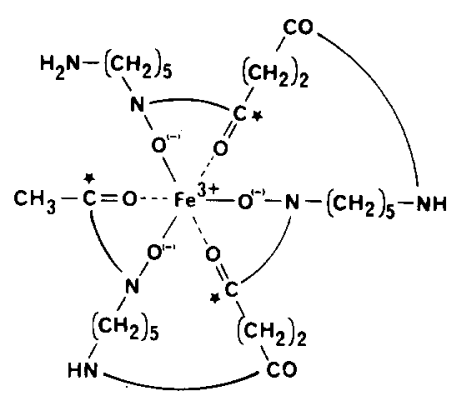

Fig. 1. The structure of desferrioxamine (A) and the iron chelate ferrioxamine (B).

Although chloramines retain the oxidizing equivalents of $\mathrm{HOCl}$, the experiments of Thomas et al. ${ }^{16-19}$ have clearly demonstrated that their toxicity towards cellular targets is dependent on their ability to penetrate cell membranes. Lipophilic chloramines such as monochloramine retain or enhance the toxicity of $\mathrm{HOCl}$, whereas hydrophilic chloramines do not penetrate the cell membrane and, therefore, limit the toxicity towards cellular targets. ${ }^{16,19}$

The aim of this study was to determine whether reaction of $\mathrm{HOCl}$ with desferrioxamine or ferrioxamine could prevent $\mathrm{HOCl}$-mediated cellular injury. As a model, we have used red blood cells, monitoring cell lysis as a membrane event, and haemoglobin oxidation. The ability of desferrioxamine and ferrioxamine to prevent these reactions was compared with taurine, an amine compound known to inhibit $\mathrm{HOCl}$-mediated red blood cell lysis. ${ }^{19,20}$ We also investigated whether reaction with $\mathrm{HOCl}$ affects the subsequent ability of desferrioxamine to form iron complexes.

\section{MATERIALS AND METHODS}

\section{Materials}

$\mathrm{NaOCl}$, from Fisher Chemical Co. was diluted in phosphate buffer, $\mathrm{pH}$ 7.4. The concentration of $\mathrm{HOCl} /$ $\mathrm{OCl}^{-}$was determined after reaction with monochlorodimedon, with the decrease in $A_{290}$ being used to calculate the loss of monochlorodimedon. The extinction coefficient used was $1.99 \times 10^{4} \mathrm{M}^{-1}$. $^{21}$ Desferrioxamine was obtained from CIBA Laboratories, Horsham, England as desferrioxamine mesylate (desferal). Ferrioxamine was prepared by the addition of a molar equivalent of $\mathrm{FeCl}_{3}$ to desferrioxamine in solution. 5-Thio-2-nitrobenzoic acid (TNB) was formed from 5,5'-dithio-bis(2-nitrobenzoic acid) (DTNB), either by reduction with $\mathrm{NaBH}_{4}$ followed by incubation at $37^{\circ} \mathrm{C}$ overnight to remove any remaining reducing agents, ${ }^{22}$ or by exposing DTNB to $0.1 \mathrm{M} \mathrm{NaOH}$ for 2 min, then readjusting the $\mathrm{pH}$ to 7.4 with $\mathrm{HCl} .{ }^{23}$ Unless stated otherwise, all reagents were from Sigma Chemical Co., St. Louis, MO, USA.

\section{Lysis of red blood cells and haemoglobin oxidation}

Red cells were prepared from freshly drawn peripheral blood of normal donors. After washing 5 times with $0.01 \mathrm{M}$ sodium phosphate, $\mathrm{pH} 7.4$, containing $138 \mathrm{mM} \mathrm{NaCl}$ and $2.7 \mathrm{mM} \mathrm{KCl}$ (PBS) to remove plasma and white cells, a suspension of $0.25 \%(\mathrm{v} / \mathrm{v})$ was prepared in PBS. To the red cell suspension (0.9 $\mathrm{mL})$ in a cuvette, $\mathrm{HOCl} / \mathrm{OCl}^{-}(0.1 \mathrm{~mL})$ was added with rapid mixing. The rate of red cell lysis was determined by continuously monitoring the turbidity of the suspension at $700 \mathrm{~nm}$. When desferrioxamine, ferrioxamine, or taurine was present, these were added to the red cell suspension prior to addition of $\mathrm{HOCl}$.

After reaction with $\mathrm{HOCl}$, the sample was centrifuged at $400 \times \mathrm{g}$ for $5 \mathrm{~min}$. The red cell pellet (if any) was lysed in $1 \mathrm{~mL} 5 \mathrm{mM}$ phosphate buffer, $\mathrm{pH}$ 7.4. This was combined with the supernatant and the extent of hemoglobin oxidation in the total sample, representing lysed and unlysed cells, was determined by reading the absorbances at $700,630,577$, and 560 $\mathrm{nm}$. The concentration $(\mathrm{mM})$ of oxyHb, MetHb, and hemichrome were calculated from the absorbances after correcting for turbidity by subtraction of the 700 nm reading. ${ }^{24}$

$$
\begin{aligned}
\text { OxyHb } & =26.7 \mathrm{~A}_{577}-7.8 \mathrm{~A}_{630}-20.1 \mathrm{~A}_{560} \\
\text { MetHb } & =5.7 \mathrm{~A}_{577}+71.6 \mathrm{~A}_{630}-12.1 \mathrm{~A}_{560} \\
\text { Hemichrome } & =-29.7 \mathrm{~A}_{577}-28.1 \mathrm{~A}_{630}+53.7 \mathrm{~A}_{560}
\end{aligned}
$$

The levels of desferrioxamine, ferrioxamine, and taurine which gave $50 \%$ inhibition of lysis and $\mathrm{Hb}$ oxidation were estimated from reciprocal plots of percent inhibition versus concentration of inhibitor.

\section{Chloramine formation}

The amount of chloramine formed after reaction of $\mathrm{HOCl}$ with amines was determined by the oxidation of TNB to DTNB, according to the stoichiometry:

$$
\begin{aligned}
& 2 \mathrm{R}-\mathrm{SH}+\mathrm{RNHCl} \longrightarrow \longrightarrow \\
& \mathrm{R}-\mathrm{S}-\mathrm{S}-\mathrm{R}+\mathrm{RNH}_{2}+\mathrm{H}^{+}+\mathrm{Cl}^{-}
\end{aligned}
$$


Solutions of desferrioxamine or taurine $(0.9 \mathrm{~mL}$ of 1.1 $\mathrm{mM}$ each) were reacted with $\mathrm{HOCl}$ in $100 \mu \mathrm{L}$ to give a final concentration of $0.25-3 \mathrm{mM}$. $\mathrm{HOCl}$ was added slowly while stirring vigorously on a vortex mixer, and the tubes were left for $10 \mathrm{~min}$ at room temperature to ensure complete reaction of $\mathrm{HOCl}$ with the amine compound. Aliquots of $25 \mu \mathrm{L}$ and $50 \mu \mathrm{L}$ were removed and mixed with excess TNB. The decrease in absorbance at $412 \mathrm{~nm}$ was measured and the amount of TNB oxidized calculated using an extinction coefficient of $1.36 \times 10^{4} \mathrm{M}^{-1} \mathrm{~cm}^{-1} .18$

\section{Iron binding by desferrioxamine}

The ability of desferrioxamine to chelate Fe after reaction with $\mathrm{HOCl}$ was determined. Desferrioxamine ( $1 \mathrm{mM}$ ) was reacted with $0.4-4 \mathrm{mM} \mathrm{HOCl}$ in a final volume of $1 \mathrm{~mL}$, and after $10 \mathrm{~min}$ at room temperature, $\mathrm{FeCl}_{3}$ was added to $1 \mathrm{mM}$ final concentration. The amount of ferrioxamine formed was measured from the absorbance maximum at $430 \mathrm{~nm}^{9}$ and determined from a standard curve of ferrioxamine of known concentrations.

\section{RESULTS}

Inhibition of HOCl-mediated red cell lysis and Hb oxidation

Addition of $\mathrm{HOCl}$ to red cell suspensions caused lysis of the cells, measured as a decrease in turbidity at $700 \mathrm{~nm}$ (Fig. 2A), and Hb oxidation (Fig. 2B). Lysis was immediate on addition of $\mathrm{HOCl}$ at concentrations above $0.3 \mathrm{mM}$ and below this showed a lag time of $1-$ $3 \mathrm{~min}$. These results are similar to those of Grisham et al. ${ }^{19}$ Spectral analysis showed that hemoglobin was oxidized to methemoglobin and hemichrome, a denatured ferric derivative (Fig. 2B). In all subsequent experiments with inhibitors, we used $0.5 \mathrm{mM} \mathrm{HOCl}$ (final concentration) with $0.9 \mathrm{~mL}$ of suspension of $0.25 \%$ red cells.

As shown in Fig. 3, desferrioxamine was more efficient than ferrioxamine or taurine at preventing $\mathrm{HOCl}$-mediated cell lysis. Concentrations at which $50 \%$ inhibition was observed were 7-8 times lower than those of either ferrioxamine or taurine (Table 1). In turn, ferrioxamine was approximately 1.5 times more efficient than taurine at preventing red cell lysis $(p<0.001)$ (Fig. 3 and Table 1). Desferrioxamine was also 6-8 times more efficient than either ferrioxamine or taurine at inhibiting $\mathrm{Hb}$ oxidation by $\mathrm{HOCl}$ (Fig. 4 and Table 1).

\section{Chloramine formation}

The yields of long-lived chloramines produced by reaction of desferrioxamine, ferrioxamine, and taurine with $\mathrm{HOCl}$ were determined by reaction with TNB. With taurine virtually all the oxidizing equivalents were recovered as a chloramine, as has been shown previously by others. ${ }^{25}$ Approx. $90 \%$ of the oxidizing equivalents added to ferrioxamine were recovered (Fig. $5)$. In contrast, reaction of desferrioxamine with $\mathrm{HOCl}$ resulted in a lower recovery of chloramine (Fig. 5). At a ratio of $\mathrm{HOCl}$ to desferrioxamine of $0.25: 1$ the yield of chloramine was approximately $70 \%$, but it decreased to less than $30 \%$ when the ratio was $3: 1$. These results suggest that $\mathrm{HOCl}$ can react with the
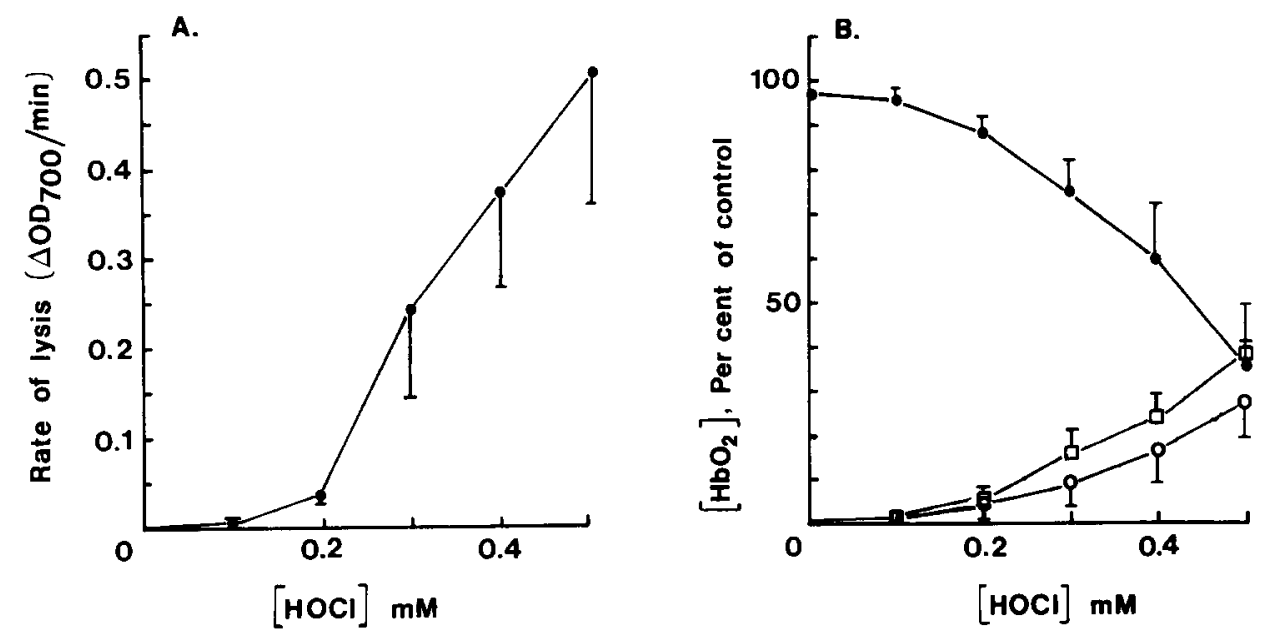

Fig. 2. The effect of $\mathrm{HOCl}$ concentration on the rate of (A) red cell lysis and (B) Hb oxidation. HOCl was added to a $0.25 \%$ suspension of red blood cells and the rate of lysis measured by continuously monitoring the absorbance at $700 \mathrm{~nm}$. The amount of oxidized $\mathrm{Hb}$ was determined as described in the Methods section. (•) OxyHb; $(0) \mathrm{MetHb}$; $(\square)$ hemichrome. The means \pm $S D$ of 7-11 experiments are shown. 


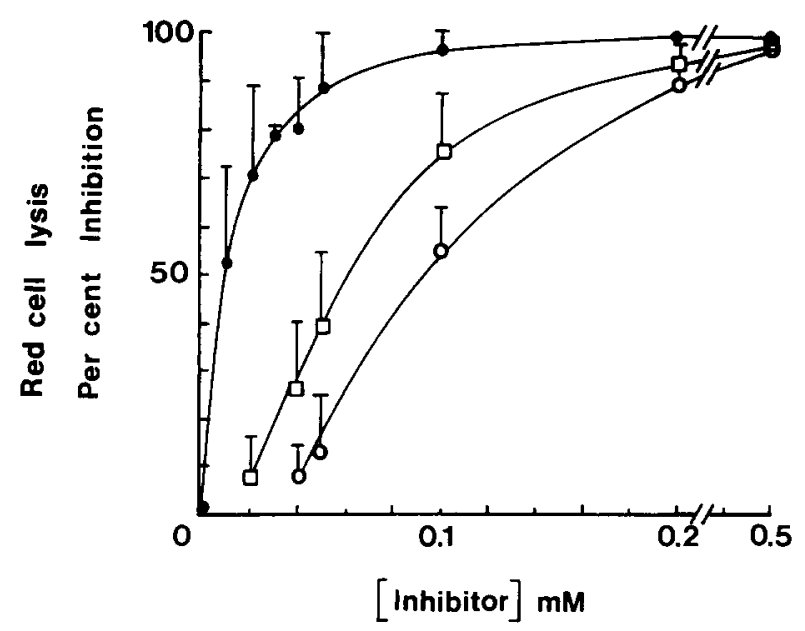

Fig. 3. Inhibition of HOCl-mediated red cell lysis by desferrioxamine $(\bullet)$, ferrioxamine $(\square)$, and taurine $(0)$. $\mathrm{HOCl}(0.5 \mathrm{mM})$ was added to suspensions of $0.25 \%$ red cells in PBS plus varying concentrations of inhibitor. The results show the means $\pm S D$ of 5-7 experiments.

desferrioxamine molecule at sites other than the terminal amine group.

Whether the chloramines could lyze red cells and oxidize $\mathrm{Hb}$ was investigated. Desferrioxamine, ferrioxamine, and taurine ( $1 \mathrm{mM}$ each) were reacted with $1 \mathrm{mM} \mathrm{HOCl}$ for $10 \mathrm{~min}$ and the formation of chloramines was tested by reaction with TNB. Each chloramine was incubated with a $0.25 \%$ suspension of red cells for $1 \mathrm{~h}$ at room temperature and the extent of lysis and $\mathrm{Hb}$ oxidation determined. A small amount of $\mathrm{Hb}$ oxidation was seen with desferrioxamine and ferrioxamine, and none with taurine (Table 2). No cell lysis was observed in any of the samples. In contrast, when the chloramines were incubated with a fresh hemolysate, there was rapid oxidation of $\mathrm{Hb}$ (Table 2). These results demonstrate that the chloramine derivatives of desferrioxamine and ferrioxamine cannot gain access to intracellular molecules and confine their oxidizing capacity to the extracellular medium.

\section{Effect of $\mathrm{HOCl}$ on iron chelation by desferrioxamine}

The ability of desferrioxamine to complex iron after reaction with $\mathrm{HOCl}$ was determined. Figure 6 shows

Table 1. The Concentrations of Desferrioxamine, Ferrioxamine, and Taurine Which Gave 50\% Inhibition of HOCl-Mediated Red Cell Lysis and Hb Oxidation

\begin{tabular}{lcc}
\hline & Red Cell Lysis & Hb Oxidation \\
\cline { 2 - 3 } & \multicolumn{1}{c}{ Concentration $(\mu \mathrm{M})$} \\
\hline Desferrioxamine & 9 & 13 \\
Ferrioxamine & 67 & 100 \\
Taurine & 105 & 97 \\
\hline
\end{tabular}

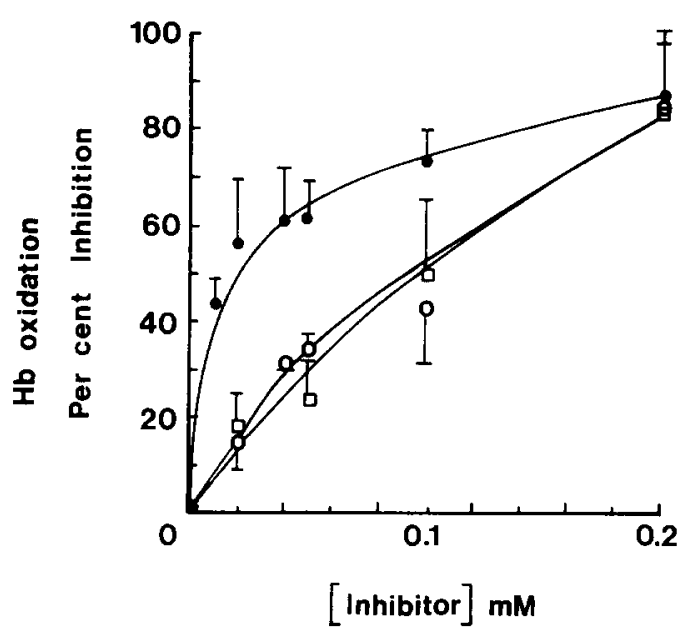

Fig. 4. Inhibition of $\mathrm{HOCl}$-mediated Hb oxidation by desferrioxamine $(\bullet)$, ferrioxamine $(\square)$ and taurine $(O)$. Conditions were as described for Figure 3. The decrease in oxyHb was measured to determine $\% \mathrm{Hb}$ oxidized. Means $\pm S D$ of $5-7$ experiments are shown.

that the addition of a two-fold excess of $\mathrm{HOCl}$ decreased the ability of desferrioxamine to bind iron by $50 \%$, and a four-fold excess almost completely inhibited iron binding. Reaction with $\mathrm{HOCl}$ did not alter the absorbance of desferrioxamine at $430 \mathrm{~nm}$. $\mathrm{HOCl}$ added to preformed ferrioxamine in up to a two-fold molar excess did not cause iron release, since no changes in the absorbance spectrum were observed.

\section{DISCUSSION}

Iron chelation by desferrioxamine has been widely used to determine the involvement of $\mathrm{OH}^{*}$ in free rad-

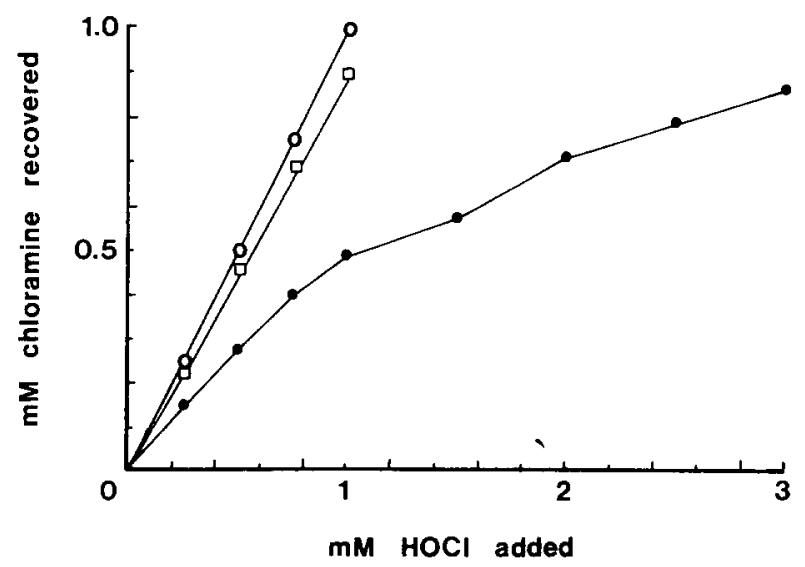

Fig. 5. Recovery of oxidizing equivalents from desferrioxamine $(\bullet)$, ferrioxamine ( $\square$ ) and taurine $(0)$, after reaction with $\mathrm{HOCl}, 1 \mathrm{mM}$ compound was reacted with increasing concentrations of $\mathrm{HOCl}$ and the amount converted to a long-lived chloramine was determined by reaction with TNB. The results shown are from one experiment. Similar results were found on two other occasions, and the standard deviation between estimates was $8 \%$ or less. 
Table 2. Oxidation of $\mathrm{Hb}$ by the Chloramine Derivatives of Desferrioxamine, Ferrioxamine, and Taurine. Red blood cells $(0.25 \%)$ or hemolysate were incubated with $1 \mathrm{mM}$ of each compound for $\mathrm{l} \mathrm{h}$ and the extent of $\mathrm{Hb}$ oxidation measured as described under methods. Means $\pm S D$ of three separate experiments are shown.

\begin{tabular}{lcc}
\hline \multicolumn{1}{c}{ Addition } & Red Cells & Hemolysate \\
\hline & \multicolumn{2}{c}{$\%$ OxyHb remaining } \\
\cline { 2 - 3 } & $100 \pm 0$ & $100 \pm 0$ \\
None & $92 \pm 2$ & $7 \pm 12$ \\
Desferrioxamine-NHCl & $97 \pm 2$ & $0 \pm 0$ \\
Ferrioxamine-NHCl & $101 \pm 1$ & $16 \pm 10$ \\
Taurine-NHCl &
\end{tabular}

ical mechanisms. While its use in controlled experimental conditions may be well defined, its specificity as an inhibitor in more complex radical-generating systems is less certain. When neutrophils or monocytes are the generating source, the major oxidant measured in the extracellular medium is $\mathrm{HOCl}$, formed by the reaction of myeloperoxidase with $\mathrm{H}_{2} \mathrm{O}_{2}{ }^{26.27}$ Our experiments have shown that desferrioxamine reacts readily with $\mathrm{HOCl} / \mathrm{OCl}^{-}$and, at the concentrations often used in experimental systems, ${ }^{7-10}$ prevented red cell lysis. Hb oxidation, which under these conditions occurs extracellularly subsequent to lysis, ${ }^{19}$ was also inhibited. Ferrioxamine also reacted with $\mathrm{HOCl}$, but was a much less efficient inhibitor than desferrioxamine.

Our results have implications for the interpretation of experiments in which these compounds are used to determine the involvement of $\mathrm{OH}^{*}$ in free radical reactions mediated by neutrophils. In some studies, greater inhibition of neutrophil cytotoxic reactions by desferrioxamine than ferrioxamine has been taken as an indication of the involvement of $\mathrm{OH}^{\prime}$ generated by the iron-catalyzed Haber-Weiss reaction. ${ }^{7-10}$ Our experiments showing that desferrioxamine is a more efficient scavenger of $\mathrm{HOCl}$ than is ferrioxamine imply that selective inhibition of neutrophil-mediated cytotoxicity by desferrioxamine could also indicate an $\mathrm{HOCl}$-mediated reaction. This is particularly so when inhibition requires millimolar concentrations of desferrioxamine. Our results are in agreement with a recent report which showed that desferrioxamine prevents iodination reactions by myeloperoxidase and eosinophil peroxidase. ${ }^{28}$ The specificity of desferrioxamine has also been questioned in other studies showing that it can react with $\mathrm{O}_{2}-$ to form a nitroxide radical. ${ }^{29}$

$\mathrm{HOCl}$ reacts readily with amines to produce chloramines. These retain the oxidizing equivalents of $\mathrm{HOCl}$, but their biological reactivity can be modified by their hydrophobicity and consequent ability to penetrate cell membranes. Hence, lipophilic chloramines

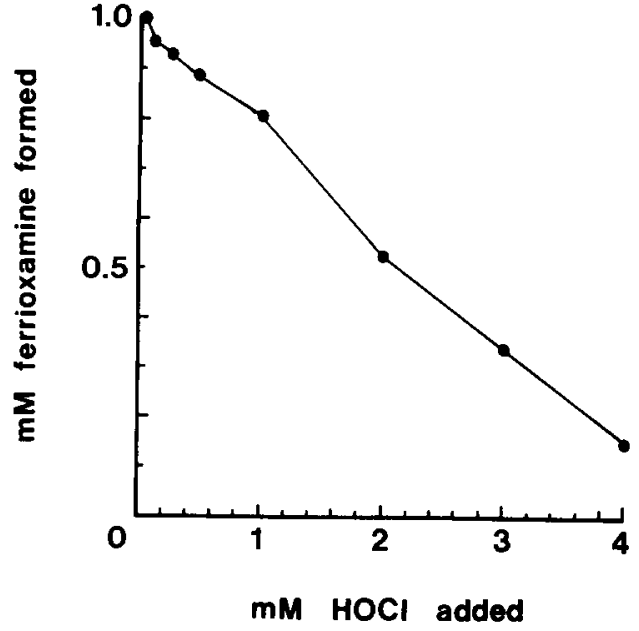

Fig. 6. The effect of $\mathrm{HOCl}$ on the iron-binding ability of desferrioxamine. Desferrioxamine ( $1 \mathrm{mM})$ was reacted with $\mathrm{HOCl}$ and its subsequent ability to chelate $\mathrm{Fe}^{3+}$ determined by measuring the amount of ferrioxamine formed by its absorbance at $430 \mathrm{~nm}$. The results shown are from one experiment and are representative of three separate experiments which agreed to within $5 \%$.

cause cell lysis similarly to $\mathrm{HOCl}$ whereas hydrophilic chloramines are largely confined to the extracellular medium and are much less toxic to cellular targets. ${ }^{16-19}$ We showed that desferrioxamine and ferrioxamine, like taurine, formed chloramine derivatives. Extended incubation of red cells with the chloramines did not result in cell lysis or significant $\mathrm{Hb}$ oxidation. In contrast, $\mathrm{Hb}$ in hemolysate was readily oxidized. Both desferrioxamine and ferrioxamine are hydrophilic molecules,$^{30}$ hence their chloramine derivatives, like taurine chloramine, should not penetrate the cell membrane and this would explain why lysis was prevented. In a recent study, Wasil et al. ${ }^{31}$ showed that desferrioxamine did not protect $\alpha_{1}$-antitrypsin from $\mathrm{HOCl}$ dependent inactivation. While they inferred from this that desferrioxamine did not react with $\mathrm{HOCl}$, it is likely that oxidation of $\alpha_{1}$-antitrypsin occurred by reaction with the desferrioxamine chloramine derivative. Hence, their results do not exclude a reaction between desferrioxamine and $\mathrm{HOCl}$. Indeed, inhibition of $\mathrm{HOCl}$-mediated events by desferrioxamine will be more effective when cellular targets are used.

On reaction of ferrioxamine with $\mathrm{HOCl}$, we found that almost all the oxidizing equivalents were recovered as chloramine, indicating that the terminal $-\mathrm{NH}_{2}$ group was the primary reaction site. With desferrioxamine, less than half the oxidizing equivalents were recovered as chloramine, suggesting that sites other than the terminal - $\mathrm{NH}_{2}$ competed successfully for the $\mathrm{HOCl}$. This could involve the iron-binding sites, since reaction with $\mathrm{HOCl}$ prevented subsequent iron chelation. From its known chemistry ${ }^{32} \mathrm{HOCl}$ reacts most readily with alkenes, and it is therefore likely that 
chlorination of the enol tautomers (marked with a star in Fig. 1)<smiles>C=C(O)N(O)C#CCC(=O)N(C)O</smiles>

would destroy the iron-binding site. This reaction would explain the greater efficiency of desferrioxamine as a scavenger of $\mathrm{HOCl}$, since the iron-binding hydroxamic acid is not available for reaction in ferrioxamine (Fig. 1).

The differences found in the abilities of desferrioxamine and ferrioxamine to prevent neutrophil-mediated oxidative events could be further accentuated: The chloramines formed are able to oxidize extracellular components, and since desferrioxamine forms less chloramine than does ferrioxamine, it will also be considerably less toxic.

The ability of $\mathrm{HOCl}$ to destroy the iron-binding capacity of desferrioxamine is also of interest with regard to the microbicidal function of neutrophils. Hydroxamic acid-type iron chelators are released by bacteria to scavenge iron required for bacterial growth. ${ }^{33} \mathrm{HOCl}-$ mediated destruction of the iron-binding sites of these molecules could severely restrict bacterial replication and this may be an additional microbicidal mechanism for the myeloperoxidase- $\mathrm{H}_{2} \mathrm{O}_{2}$-chloride system.

Acknowledgements - We are grateful to Drs. Henry Rosen, Christine Winterbourn, Tony Kettle, and Seymour Klebanoff for helpful discussion, and to Dr. Winterbourn for critical reading of the manuscript.

\section{REFERENCES}

1. Babior, B. M. Oxidants from phagocytes: agents of defense and destruction. Blood 64:959-966; 1984.

2. Weiss, S. J.; LoBuglio, A. F. Biology of disease. Phagocytegenerated oxygen metabolites and cellular injury. Lab. Invest. 47:5-18; 1982

3. Fantone, J, C.; Ward, P. A. Role of oxygen-derived free radicals and metabolites, in leukocyte-dependent inflammatory reactions. Am. J. Pathol. 107:395-418; 1982.

4. Cochrane, C. G. Role of granulocytes in immune-complex-induced tissue injuries. Inflammation 2:219-333; 1977.

5. Rehan, A.; Johnson, K. J.; Wiggins, R. C.; Kunkel, R. G.; Ward, P. A. Evidence for the role of oxygen radicals in acute nephrotoxic nephritis. Lab. Invest. 51:396-403; 1984.

6. Simpson, P. J.; Todd, R. F.; Fantone, J. C.; Michelson, J. K.; Griffin, J. D.; Lucchesi, B. R. Reduction of experimental canine myocardial reperfusion injury by a monoclonal antibody (antiMcl, anti-cD-116) that inhibits leukocyte adhesion. J. Clin. Invest. 81:624-629; 1988.

7. Varani, J.; Fligiel, S. E. G.; Till, G. O.; Kunkel, R. G.; Ryan, U. S.; Ward, P. A. Pulmonary endothelial cell killing by human neutrophils. Possible involvement of hydroxyl radical. Lab. Invest. 53:656-663; 1985.

8. Kyle, M. E.; Miccadei, S.; Nakae, D.; Farber, J. L. Superoxide dismutase and catalase protect cultured hepatocytes from the cytotoxicity of acetominophen. Biochem. Biophys. Res. Commun. 149:889-896; 1987.
9. Gannon, D. E.; Varani, J.; Phan, S. H.; Ward, J. H.; Kaplan, J.; Till, G. O.; Simon, R. H.; Ryan, U. S.; Ward, P. A. Source of iron in neutrophil-mediated killing of endothelial cells. $L a b$. Invest. 57:37-44; 1987

10. Till, G. O.; Hatherill, J. R.; Tourtellotte, W. W.; Lutz, M. J.; Ward, P. A. Lipid peroxidation and acute lung injury after thermal trauma to skin. Evidence of a role for hydroxyl radical. Am. J. Pathol. 119:376-384; 1985.

11. Klebanoff, S. J. Oxygen metabolism and the toxic properties of phagocytes. Ann. Int. Med. 93:480-489; 1980.

12. Rosen, H.; Klebanoff, S. J. Oxidation of Escherichia coli iron centers by the myeloperoxidase-mediated microbicidal system. J. Biol. Chem. 257:13731-13735; 1982.

13. Albrich, J. M.; McCarthy, C. A.; Hurst, J. K. Biological reactivity of hypochlorous acid: implications for microbicidal mechanisms of leukocyte myeloperoxidase. Proc. Natl. Acad. Sci. (USA) 78:210-214; 1981 .

14. Albrich, J. M.; Gilbaugh, J. H.; Callahan, K. B.; Hurst, J. K. Effect of the putative neutrophil-mediated toxin, hypochlorous acid, on membrane permeability and transport systems of Escherichia coli. J. Clin. Invest. 78:177-184; 1986.

15. Thomas, E. L. Myeloperoxidase, hydrogen peroxide, chloride antimicrobial system: nitrogen chlorine derivatives of bacterial components in bactericidal action against Escherichia coli. Infection and Immunity 23:522-531; 1979.

16. Thomas, E. L.; Jefferson, M. M.; Grisham, M. B. Myeloperoxidase catalysed incorporation of amines into proteins: Role of hypochlorous acid and dichloramines. Biochemistry 21:6299-6308: 1982.

17. Grisham, M. B.; Jefferson, M. M.; Melton, D. F.; Thomas, E. L. Chlorination of endogenous amines by isolated neutrophils. Ammonia-dependent bactericidal, cytotoxic, and cytolytic activities of the chloramines. J. Biol. Chem. 259:10404-10413; 1984.

18. Thomas, E. L.; Grisham, M. B.; Jefferson, M. M. Myeloperoxidase dependent effect of amines on functions of isolated neutrophils. J. Clin. Invest. 72:441-454; 1983

19. Grisham, M. B.; Jefferson, M. M.; Thomas, E. L. Role of monochloramine in the oxidation of erythrocyte haemoglobin by stimulated neutrophils. J. Biol. Chem. 259:6676-6772; 1984.

20. Dallegri, F.; Ballestrero, G.; Frumento, G.; Patrone, F. Erythrocyte lysis by PMA-triggered neutrophil polynuclears: evidence for a hypochlorous acid-dependent process. Immunology 55:639-645; 1985.

21. Winterbourn, C. C. Comparative reactivities of various biological compounds with myeloperoxidase-hydrogen peroxide-chloride, and similarity of the oxidant to hypochlorite. Biochim. Biophys. Acta 840:204-210; 1985

22. Aune, T. M.; Thomas, E. L. Accumulation of hypothiocycanite ion during peroxidase-catalysed oxidation of thiocyanate ion. Eur. J. Biochem. 80:209-214; 1977

23. Riddles, P. W.; Blakely, R. L.; Zerner, B. Reassessment of Ellman's reagent. Meth. Enz. 91:49-60; 1983.

24. Szebeni, J.; Winterbourn, C. C.; Carrell, R. W. Oxidative interactions between haemoglobin and membrane lipid. A liposome model. Biochem. J. 220:685-692; 1984.

25. Weiss, S. J.; Klein, R.; Slivka, A.; Wei, M. Chlorination of taurine by human neutrophils. Evidence for hypochlorous acid generation. J. Clin. Invest. 70:598-607; 1982.

26. Winterbourn, C. C. Myeloperoxidase as an effective inhibitor of hydroxyl radical production. Implications for the oxidative reactions of neutrophils. J. Clin. Invest. 78:545-550; 1986

27. Henderson, W. R.; Klebanoff, S. J. Leukotriene production and inactivation by normal, chronic granulomatous disease and myeloperoxidase-deficient neutrophils. J. Biol. Chem. 258:13522$13527 ; 1983$.

28. Klebanoff, S. J.; Waltersdorf, A. M. Inhibition of peroxidasecatalysed reactions by desferrioxamine. Arch. Biochem. Biophys. 264:600-606; 1988.

29. Davies, M. J.; Donkor, R.; Dunster, C. A.; Gee, C. A.; Jonas, S.; Willson, R. L. Desferrioxamine (desferal) and superoxide 
free radicals. Formation of an enzyme-damaging nitroxide. Biochem. J. 246:725-729; 1987.

30. McCall, J. M. Liquid-liquid partition coefficients by HPLC. $J$. Med. Chem. 18:549-552; 1975.

31. Wasil, M.; Halliwell, B.; Grootveld, M.; Moorhouse, C. P.; Hutchison, D. C. S.; Baum, H. The specificity of thiourea, dimethylthiourea and dimethylsulphoxide as scavengers of hy- droxyl radicals. Their protection of alpha-1-antiproteinase against inactivation by hypochlorous acid. Biochem. $J$. 243:867-870; 1987.

32. Morrison, R. T.; Boyd, R. N. In: Organic chemistry. Boston: Allyn and Bacon Inc.; 1974: 186-190.

33. Letendre, E. D. The importance of iron in the pathogenesis of infection and neoplasia. TIBS 10:166-168; 1985. 